\title{
Active angiogenesis in metastatic renal cell carcinoma predicts clinical benefit to sunitinib-based therapy
}

L del Puerto-Nevado ${ }^{1}, \mathrm{~F}$ Rojo ${ }^{2}, \mathrm{~S}$ Zazo ${ }^{2}, \mathrm{C}$ Caramés ${ }^{1}, \mathrm{G}$ Rubio ${ }^{1}, \mathrm{R}$ Vega ${ }^{2}, \mathrm{C} \mathrm{Chamizo}^{2}, \mathrm{~V}$ Casado ${ }^{1}$, J Martínez-Useros ${ }^{1}$, R Rincón ${ }^{1}$, M Rodríguez-Remírez ${ }^{1}$, A Borrero-Palacios ${ }^{1}$, I Cristóbal ${ }^{1}$, J Madoz-Gúrpide ${ }^{2}$, O Aguilera ${ }^{1}$ and J García-Foncillas ${ }^{*}, 1$

${ }^{1}$ Translational Oncology Division, Oncohealth Institute, Health Research Institute FJD-UAM, University Hospital 'Fundación Jiménez Díaz', Avenida Reyes Católicos, 2, 28040 Madrid, Spain and 'Department of Pathology, Oncohealth Institute, Health Research Institute FJD-UAM, University Hospital 'Fundación Jiménez Díaz', Avenida Reyes Católicos, 2, 28040 Madrid, Spain

Background: Sunitinib represents a widely used therapy for metastatic renal cell carcinoma patients. Even so, there is a group of patients who show toxicity without clinical benefit. In this work, we have analysed pivotal molecular targets involved in angiogenesis (vascular endothelial growth factor (VEGF)-A, VEGF receptor 2 (KDR), phosphorylated (p)KDR and microvascular density (MVD)) to test their potential value as predictive biomarkers of clinical benefit in sunitinib-treated renal cell carcinoma patients.

Methods: Vascular endothelial growth factor-A, KDR and PKDR-Y1775 expression as well as CD31, for MVD visualisation, were determined by immunohistochemistry in 48 renal cell carcinoma patients, including 23 metastatic cases treated with sunitinib. Threshold was defined for each biomarker, and univariate and multivariate analyses for progression-free survival (PFS) and overall survival (OS) were carried out.

Results: The HistoScore mean value obtained for VEGF-A was 121.6 (range, 10-300); for KDR 258.5 (range, 150-300); for pKDRY1775 10.8 (range, 0-65) and the mean value of CD31-positive structures for MVD visualisation was 49 (range, 10-126). Statistical differences for PFS $(P=0.01)$ and OS $(P=0.007)$ were observed for pKDR-Y1775 in sunitinib-treated patients. Importantly, pKDRY1775 expression remained significant after multivariate Cox analysis for PFS ( $P=0.01$; HR: $5.35,95 \%$ Cl, 1.49-19.13) and for OS $(P=0.02 ; \mathrm{HR}: 5.13,95 \% \mathrm{Cl}, 1.25-21.05)$.

Conclusions: Our results suggest that the expression of phosphorylated (i.e., activated) KDR in tumour stroma might be used as predictive biomarker for the clinical outcome in renal cell carcinoma first-line sunitinib-treated patients.

Renal cell carcinoma (RCC) is the most common type of kidney cancer in adults. It accounts for $\sim 3 \%$ of adult malignancies and 90-95\% of neoplasms arising from the kidney (Kashyap et al, 2005). In Europe, RCC is diagnosed in around 88400 patients and 39300 people die each year (Ferlay et al, 2010). Therefore, despite recent advances in our understanding of molecular processes involved in the RCC pathogenesis, which have led to novel targeted therapies, it remains necessary to develop alternative strategies to improve patient outcomes (Castellano et al, 2013).

Currently, sunitinib malate or SU11248 (Sutent, Pfizer Inc., New York, NY, USA) represents a widely used therapeutic option for metastatic RCC (Scartozzi et al, 2013). This drug was approved by the United States Food and Drug Administration for treatment of patients with specific types of cancer 
(Kamba and McDonald, 2007). Its activity is based on the inhibition of vascular endothelial growth factor receptor 2 (KDR), platelet-derived growth factor receptor (PDGFR), c-KIT and fetal liver tyrosine kinase 3 (Mendel et al, 2003; Schueneman et al, 2003).

Vascular endothelial growth factor (VEGF) by binding with its specific receptor (KDR) promotes a variety of responses in endothelium, including hyperpermeability, endothelial cell growth, angiogenesis and enhanced glucose transport (Connolly, 1991; Senger et al, 1994). At the molecular level, the membrane receptor dimerises subsequently to ligand binding, and the intracellular C-terminal tyrosine residues are phosphorylated. This event activates the kinase domain initiating the signalling transduction cascade that ultimately results in increased expression of several target genes (Krause and Van Etten, 2005). The ligand-receptor interaction leads to a KDR autophosphorylation on Y1175 (Takahashi et al, 2001) that has been shown necessary for neovascularisation (McMahon, 2000), which produces high risk of angiogenesis, usually measured as an increase of microvascular density (MVD) (Chaudhary et al, 1999).

Sunitinib is recommended by international guidelines for the first-line treatment of RCC on the basis of significant reported advantages in comparison with other therapeutic options such as interferon alpha. In a phase III trial, progression-free survival (PFS) was longer and response rates were higher in patients with metastatic RCC who received sunitinib compared with those who received interferon alpha (Motzer et al, 2007; Zama et al, 2010). Furthermore, its efficacy in patients with RCC refractory to cytokine-based therapy was also demonstrated in two phase II trials (Motzer et al, 2006a, b). Despite sunitinib activity and its clear benefit, there is a group of patients who show toxicity without clinical benefit (Motzer et al, 2007, 2009). Similar outcomes are showed in the work of Tannir et al (2012), a phase II clinical trial in patients with advanced non-clear cell RCC treated with sunitinib. They proposed a therapeutically relevant biological heterogeneity in this kind of patients (Tannir et al, 2012). Therefore, there is a rising interest in identifying biomarkers that could be useful to determine the profile of candidate patients who will benefit from sunitinib treatment and, in contrast, discard those patients who could undergo toxicities, poor outcomes or being refractory to this therapy.

In this work, we have analysed several molecular targets involved in the VEGF pathway in a cohort of metastatic RCC patients treated with sunitinib. Interestingly, results obtained from this preliminary study show evidence that phosphorylated (i.e., activated) KDR-Y1775 has a potential value as predictive biomarker of clinical benefit in RCC patients treated with sunitinib-based therapies and may also contribute to the future design of more personalised therapies that improve the poor outcomes observed in patients with RCC.

\section{MATERIALS AND METHODS}

Patients. The study involved 23 biopsies from consecutive cases of clear cell metastatic RCC treated with sunitinib in first line between 2008 and 2013 obtained from the Biobank of Fundación Jiménez Díaz Hospital (Spain). To compare biomarkers' expression with baseline data, we included a control group consisting of biopsies from non-metastatic RCC patients without treatment $(n=25)$. All patients gave written informed consent and sample collection was made with the approval of the Institutional Scientific and Ethical Committee.

Clinical-pathological data were obtained from the patient medical records and included sex, age, Eastern Cooperative Oncology group (ECOG) performance status, previous nephrectomy, site of metastases, number of disease sites and Memorial Sloan-Kettering Cancer Center risk classification (MSKCC risk factors), which stratifies patients with metastatic RCC into risk categories based on the number of adverse clinical and laboratory parameters present such as levels of serum haemoglobin, serum calcium and serum lactate dehydrogenase, ECOG performance status and time between diagnosis and treatment (Motzer et al, 2002).

Immunohistochemistry. Consecutive $4 \mu \mathrm{m}$ tissue sections were obtained from formalin-fixed paraffin-embedded samples. Antigen retrieval was performed in PT-Link (Dako, Glostrup, Denmark) for $20 \mathrm{~min}$ at $95^{\circ} \mathrm{C}$ in high $\mathrm{pH}$ buffered solution (Dako). Endogenous peroxidase was blocked by immersing the sections in $0.03 \%$ hydrogen peroxide for $5 \mathrm{~min}$. Slides were washed for $5 \mathrm{~min}$ with Tris-buffered saline solution containing Tween 20 at pH 7.6 and incubated with the primary antibodies (VEGF-A (Clone VG1 M7273, Dako) specific labels VEGF-A121, VEGF-A165 and VEGF-A189 isoforms), VEGF receptor 2 (Ref. 2479, Cell Signaling Technology, Inc., Danvers, MA, USA), phosphorylated-VEGF receptor 2 at Tyr1175 (Ref. 2478, Cell Signaling Technology, Inc.) and CD31 (Clone JC70A, Dako) for $20 \mathrm{~min}$ at room temperature, followed by incubation with the appropriate anti-Ig horseradish peroxidase-conjugated polymer (EnVision, Dako) to detect antigen-antibody. Sections were then visualized with $3,3^{\prime}$-diaminobenzidine as a chromogen for $5 \mathrm{~min}$ and counterstained with haematoxylin. All immunohistochemical stainings were performed in a Dako Autostainer and the same sections incubated with non-immunized serum were used as negative

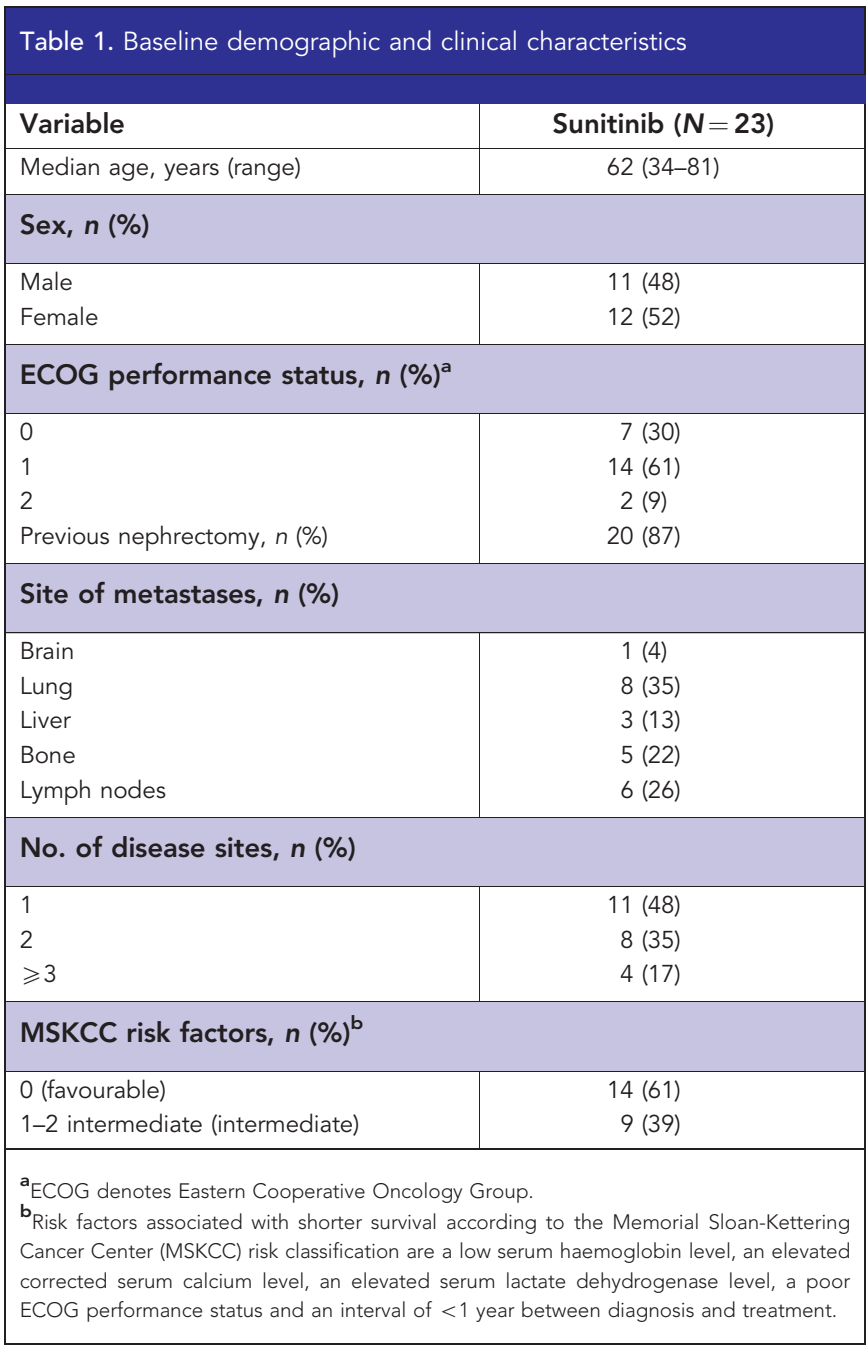


controls. As positive control, sections of a renal human tumour with known expression of the markers were stained.

Expression of the studied markers was assessed in a blinded fashion by two investigators (FR and SZ). Vascular endothelial growth factor-A was expressed in the cytoplasm of tumour cells. Vascular endothelial growth factor receptor 2 was detected in the membrane and cytoplasm of endothelial cells, and, occasionally, in activated fibroblast of tumour stroma and malignant cells. Only expression in endothelial cells was considered for the analysis. For pKDR and CD31, staining in endothelial cells was required for considering a tumour as positive. For VEGF-A, KDR and pKDR, a semiquantitative HistoScore (HScore) was calculated. The HScore was determined by estimation of the percentage of cells positively stained with low, medium or high staining intensity. The final score was determined after applying a weighting factor to each estimate. The following formula was used: HScore $=($ low $\%) \times 1+$ $($ medium $\%) \times 2+($ high $\%) \times 3$ and the results ranged from 0 to 300 . Microvascular density was calculated by the Chalkley counting procedure (Pallares et al, 2006). Briefly, a 25-point Chalkley eyepiece graticule (Olympus X250, Tokyo, Japan; Chalkley grid area $0.196 \mathrm{~mm}^{2}$ ) was applied to the ocular of the microscope and at medium magnification $(\times 200)$; the three most vascular areas of the tumour were quantified.

Statistical analysis. All statistical analyses were performed using SPSS software version 20.0 (SPSS Inc., Chicago, IL, USA). Clinical and histopathologic information as well the immunohistochemical results were collected in a database.

For potential VEGF-A and KDR association with the disease outcome, patients were divided into three expression groups (tertiles: low, medium, high) on the basis of their HScores. For MVD analysis, patients were divided according to its absolute number of CD31-positive structures. To evaluate the prognostic value of VEGF-A, KDR and MVD in our cohort, survival curves were estimated using the Kaplan-Meier method with the three groups as a factor. Significant survival differences between groups were determined by the log rank test. The third tertile was established as the cut-off point, leaving low- and high-risk patient
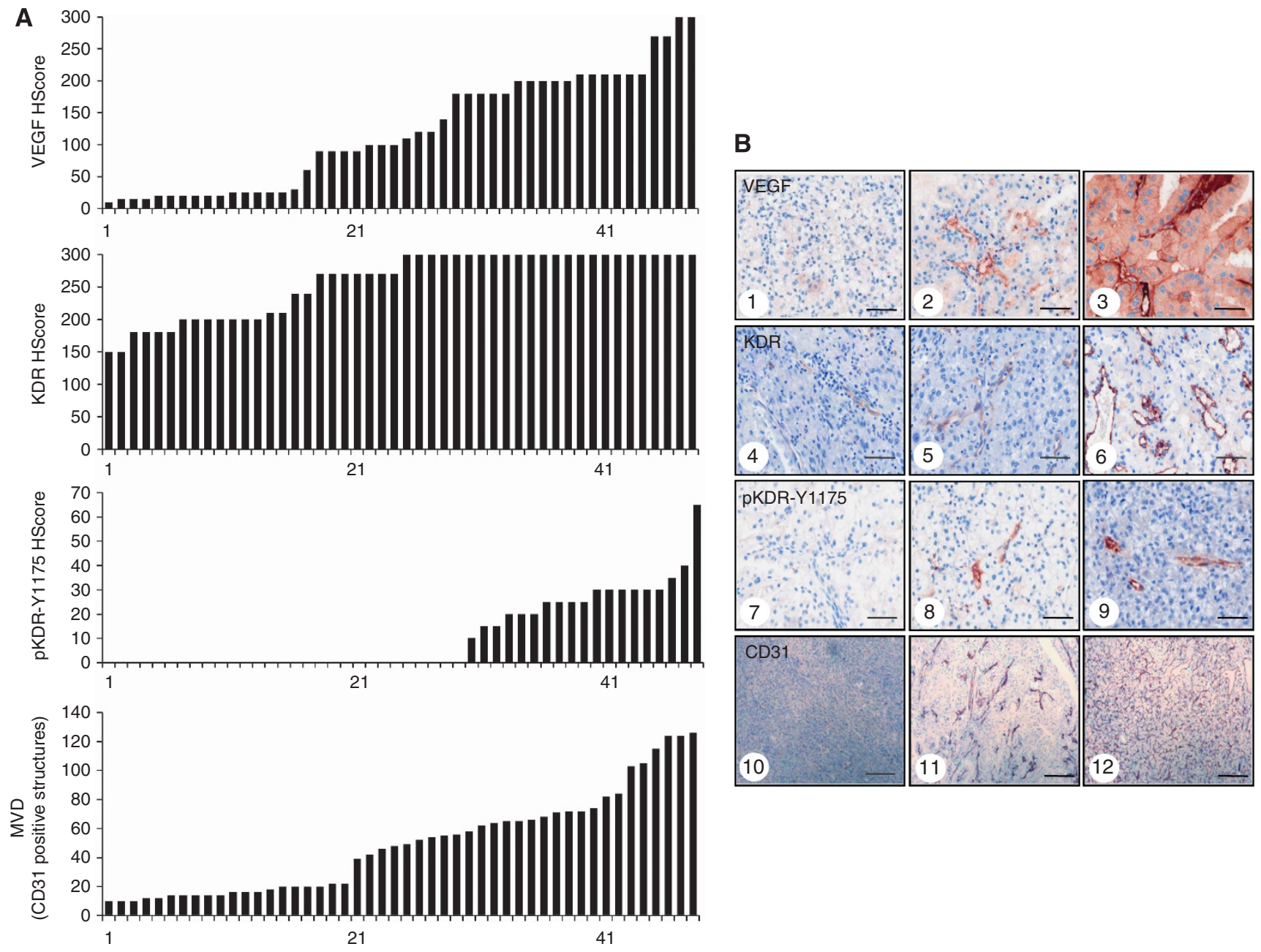

Figure 1. (A) Expression values for VEGF-A, KDR, pKDR-Y1775 and CD31 represented in histograms for each biomarker for the whole series of RCC patients. VEGF-A, KDR and PKDR-Y1775 are expressed as HScore in tumour and MVD as absolute number of CD31-positive vascular structures. (B) Representative microscopic pictures for VEGF-A, KDR, pKDR and MVD in studied metastatic RCC cases detected by immunohistochemistry. Vascular endothelial growth factor-A was detected in the cytoplasm of tumour cells with low (1), intermediate (2) and high expression (3) ( $\times 400$ magnification, scale bar: $30 \mu \mathrm{m}$ ). In addition, stromal cells showed VEGF-A staining. Expression of KDR was seen in endothelial cells, preferentially in tumour stroma. Representative images showing low (4), intermediate (5) and high expression (6) $(\times 400$ magnification, scale bar: $30 \mu \mathrm{m})$. pKDR-Y1775 was exclusively detected in the endothelial cells of tumour stroma. Tumours showed low (7), intermediate (8) and high (9) levels of pKDR in vascular structures ( $\times 400$ magnification, scale bar: $30 \mu \mathrm{m})$. Studied cases displayed important differences in MVD, detecting sparse (10), intermediate (11) and dense (12) vascular density ( $\times 40$ magnification, scale bar: $300 \mu$ m). 
groups, for MVD. The same approach was applied for VEGF-A and KDR, establishing the first tertile as the cut-off point.

For pKDR-Y1175 analysis, a cut-off point determined as positive (pKDR-Y1175 $>0$ ) and negative expression (pKDRY1175 $=0$ ) was used. Patients were divided into two groups, survival curves were estimated and differences between groups were determined by the log rank test.

Those variables that had potential prognostic suggested by univariate analysis were subjected to multivariate analysis with the Cox proportional hazards regression model. Overall survival (OS) and PFS were calculated from the date of diagnosis to the date of death or the last follow-up and to the date of sunitinib progression, respectively. A $P$-value $<0.05$ was considered as statistically significant.

\section{RESULTS}

Patient characteristics. Recruited data from patients at baseline are summarized in Table 1. The distribution of patients according to sex was similar; $52 \%$ females and $48 \%$ males. The median age for this cohort of patients was 62 years. In terms of ECOG performance status, most of patients, $61 \%$, were clustered as equal to 1 . Previous nephrectomy was carried out in $87 \%$ of the cases. Sites of metastases were diverse, including lung 35\%, liver 13\%, bone $22 \%$, brain $4 \%$ and lymph nodes $26 \%$. Number of disease sites was established as 1, 2 and $\geqslant 3(48 \%, 35 \%$ and $17 \%$, respectively).
Patients were grouped according to their MSKCC risk factor classification as favourable (61\%) and intermediate (39\%).

The control group comprised of 25 biopsies from nonmetastatic RCC patients without treatment. The median age of this group was 67 years, and the distribution of patients according to sex was $60 \%$ males and $40 \%$ females.

Vascular endothelial growth factor-A, KDR, pKDR-Y1775 and MVD in RCC. To evaluate the expression of the selected proteins, immunohistochemistry assays were performed in patients treated with SU11248. A control group was included to establish a reference value for each marker. Vascular endothelial growth factor-A expression was diffusely detected in the cytoplasm of tumour cells, as well as in the stromal, including fibroblasts, and endothelial cells. Most of the cases showed stronger staining in the tumour than stroma. Expression of KDR was seen in endothelial cells, preferentially in tumour stroma. In addition, KDR was also detected in isolated fibroblasts and malignant cells. Expression of pKDR-Y1775 was only observed in the endothelial cells of vascular structures in the tumour. Conversely, endothelial cells of vessels in adjacent non-tumoral renal tissue did not express pKDR-Y1775. Finally, CD31 expression was present in all vascular structures, both in tumour and non-tumoral renal tissue (Figure 1).

HScore values of all patients for VEGF-A, KDR and pKDR-Y1775 as well as absolute number of CD31-positive structures for MVD visualisation are represented in histograms (Figure 1). The HScore mean value obtained for VEGF-A staining was 121.6 (range, 10-300);
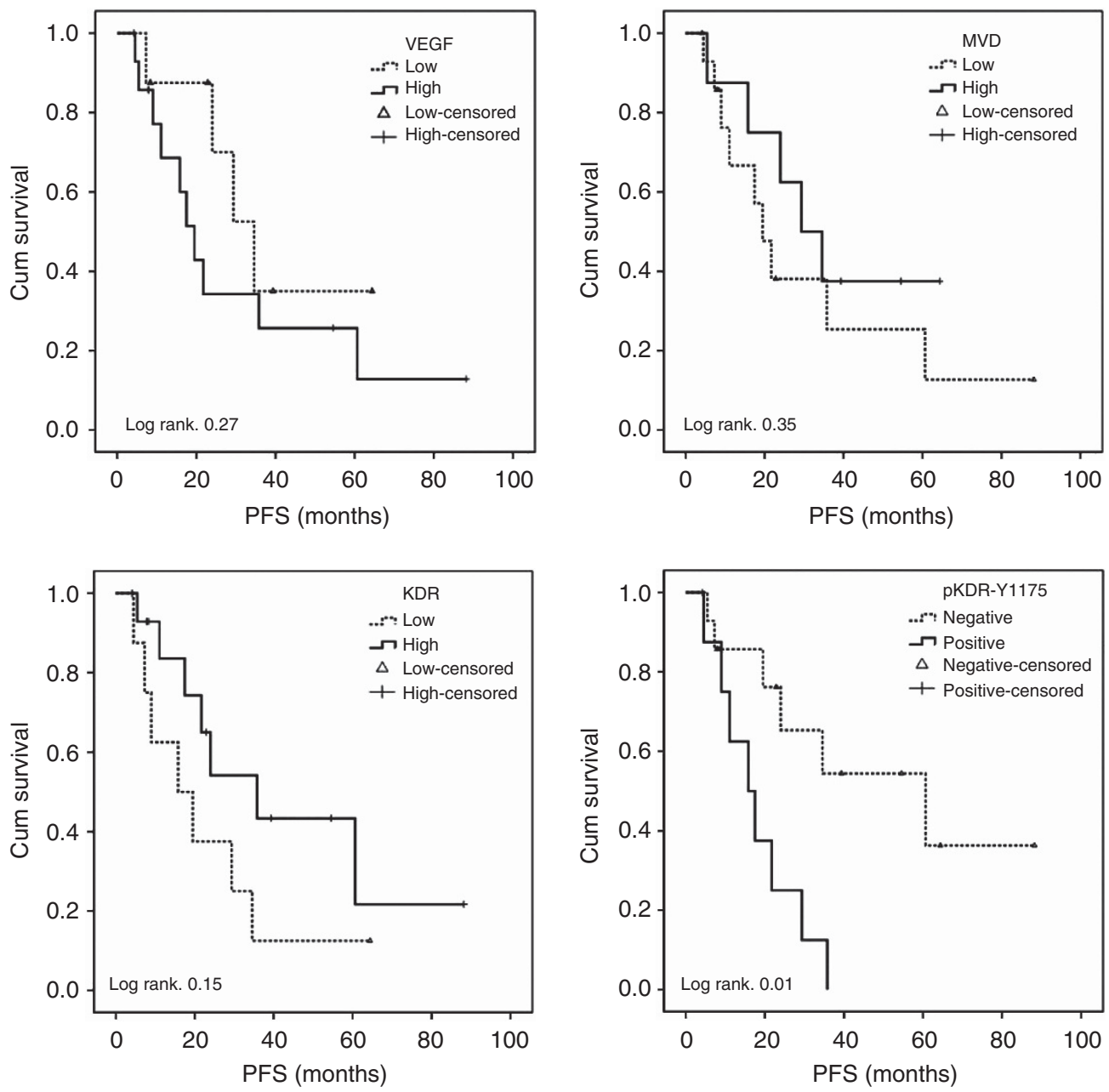

Figure 2. Kaplan-Meier analysis for PFS based on VEGF-A, KDR, pKDR-Y1775 and MVD levels in sunitinib-treated metastatic RCC patients. 
for KDR in endothelial cells 258.5 (range, 150-300); for pKDRY1775 10.8 (range, 0-65); and the mean value of CD31-positive vascular structures for MVD staining was 49 (range, 10-126).

To determine the predictive potential of these proteins in metastatic RCC patients treated with sunitinib in first line, we estimated a cut-off point of 60 for VEGF-A, of 200 for KDR, of 0 for pKDR-Y1775 and of 48 for MVD.

pKDR-Y1775 in tumour stroma predicts clinical outcome. On the basis of these cut-off points, Kaplan-Meier analysis for categorical values of each marker was performed to assess the correlation between the expression levels and prognosis status in patients treated with sunitinib in terms of PFS and OS.

Vascular endothelial growth factor-A, KDR and MVD did not show statistical difference in terms of PFS and OS (Figures 2 and 3) (Tables 2 and 3).

In relation to pKDR-Y1775, log rank test showed statistical differences for this biomarker in terms of both PFS (log rank 0.01) and OS (log rank 0.007). The median survival time for the patients without the expression of pKDR (negative) was 23.4 months (range, 5-88) for PFS and 27.6 months (range, 8-88) for OS, whereas those cases with positive pKDR-Y1775 expression were associated with worse outcome, with a median survival time of 15.8 for PFS (range, 4-36) and 25.9 months (range, 4-51) for OS. Univariate analysis showed statistical differences for both PFS $(P=0.017$, HR: 4.02, 95\% CI, 1.28-12.63) (Figure 2 and Table 2) and OS ( $P=0.015$ HR: 5.34, 95\% CI, 1.39-20.5) (Figure 3 and Table 3)
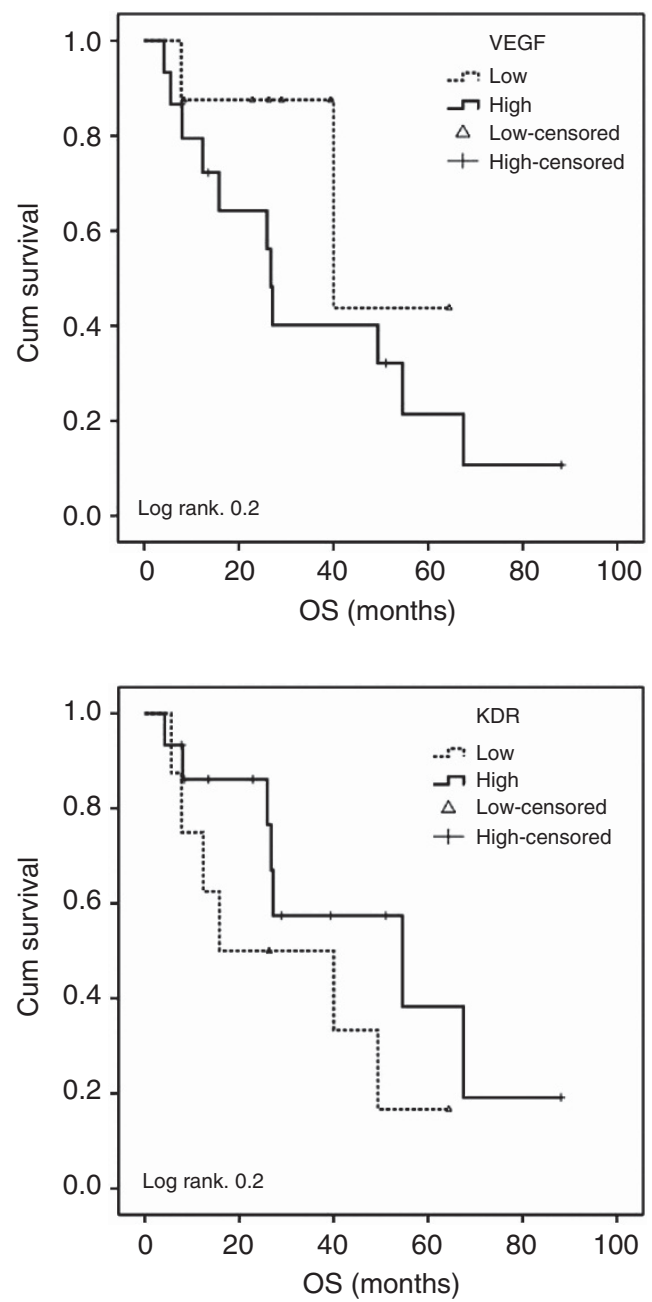

After multivariate Cox proportional hazards regression analysis, pKDR-Y1775 expression remained significant for both PFS $(P=0.01$; HR: $5.35,95 \%$ CI, $1.49-19.13)$ and OS $(P=0.02$; HR: $5.13,95 \% \mathrm{CI}, 1.25-21.05)$ suggesting that phosphorylation of $\mathrm{KDR}$ in Y1175 could be an independent predictive factor of sunitinib response in patients with clear cell metastatic RCC (Tables 2 and 3).

\section{DISCUSSION}

This study evaluates the role of VEGF-A, KDR, pKDR-Y1175 and MVD in metastatic RCC after receiving sunitinib and their potential to predict significant clinical benefit in terms of statistically longer PFS and OS.

Vascular endothelial growth factor pathway has been largely characterised in RCC as a key mechanism in the angiogenesis development (Takahashi et al, 1994; Nakagawa et al, 1997; Tomisawa et al, 1999), and as a result, a relevant therapeutic target (Rini, 2009). Sunitinib is a multitargeted receptor tyrosine kinase inhibitor of VEGF receptors, among others, which interacts with the ATP binding pocket of these kinases and acts as competitive inhibitor with ATP. Its efficacy in patients with RCC refractory to cytokine-based therapy was demonstrated in two phase II trials (Motzer et al, 2006a, b) as well as in previously untreated patients in a phase III trial (Motzer et al, 2007).
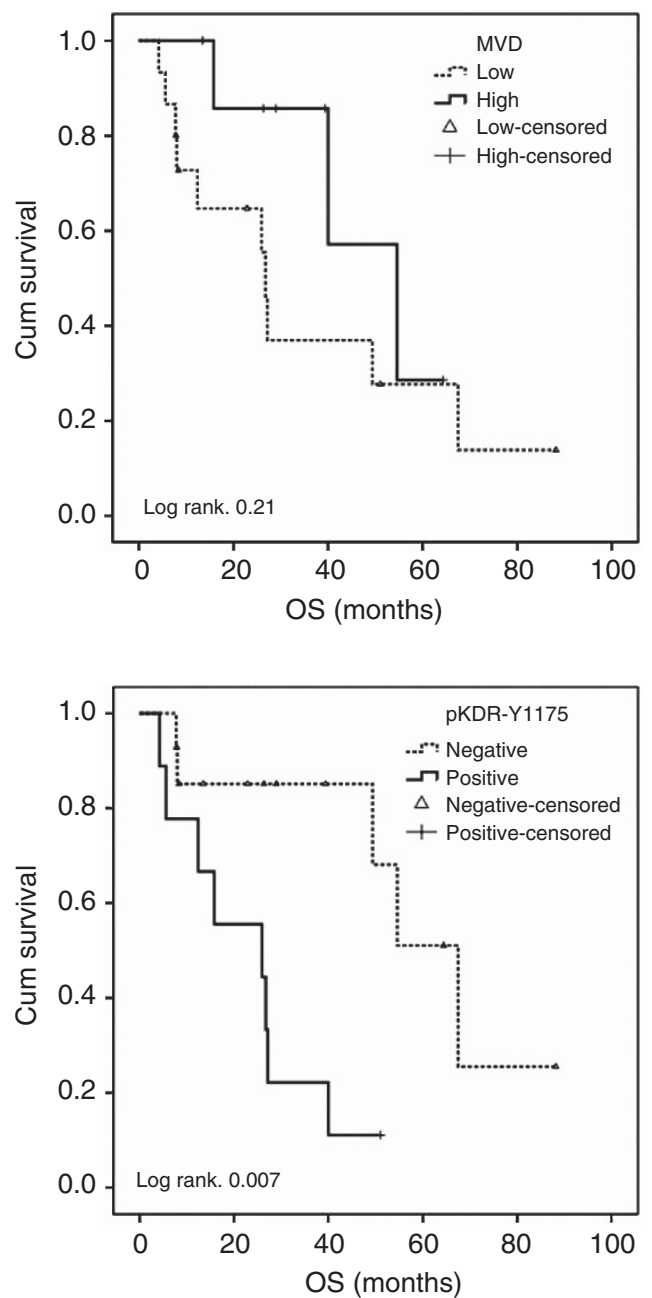

Figure 3. Kaplan-Meier analysis for OS based on VEGF-A, KDR, pKDR-Y1775 and MVD levels in sunitinib-treated metastatic RCC patients. 


\begin{tabular}{|c|c|c|c|c|c|c|c|c|}
\hline & \multicolumn{4}{|c|}{ Univariate PFS analysis } & \multicolumn{4}{|c|}{ Multivariate PFS analysis } \\
\hline & \multirow[b]{2}{*}{$\mathrm{HR}$} & \multicolumn{2}{|c|}{$95 \% \mathrm{Cl}$} & \multirow[b]{2}{*}{$P$} & \multirow[b]{2}{*}{ HR } & \multicolumn{2}{|c|}{$95 \% \mathrm{Cl}$} & \multirow[b]{2}{*}{$P$} \\
\hline & & Lower & Upper & & & Lower & Upper & \\
\hline Age & 0.98 & 0.94 & 1.02 & 0.36 & & & & \\
\hline Gender & & & & 0.18 & & & & 0.13 \\
\hline $\begin{array}{l}\text { Male } \\
\text { Female }\end{array}$ & $\begin{array}{l}1.00 \\
2.07\end{array}$ & 0.70 & 6.09 & & $\begin{array}{l}1.00 \\
2.66\end{array}$ & 0.75 & 9.48 & \\
\hline ECOG & & & & 0.26 & & & & \\
\hline $\begin{array}{l}0 \\
1-2\end{array}$ & $\begin{array}{l}1.00 \\
2.08\end{array}$ & 0.58 & 7.51 & & & & & \\
\hline No. of disease sites & & & & 0.71 & & & & \\
\hline $\begin{array}{l}1 \\
\geqslant 2\end{array}$ & $\begin{array}{l}1.00 \\
1.22\end{array}$ & 0.42 & 3.55 & & & & & \\
\hline MSKCC risk factors & & & & 0.45 & & & & 0.66 \\
\hline $\begin{array}{l}\text { Favourable } \\
\text { Intermediate }\end{array}$ & $\begin{array}{l}1.00 \\
1.52\end{array}$ & 0.5 & 4.62 & & $\begin{array}{l}1.00 \\
1.32\end{array}$ & 0.37 & 4.67 & \\
\hline VEGF & & & & 0.28 & & & & \\
\hline $\begin{array}{l}\text { Low } \\
\text { High }\end{array}$ & $\begin{array}{l}1.00 \\
1.9\end{array}$ & 0.59 & 6.12 & & & & & \\
\hline KDR & & & & 0.16 & & & & \\
\hline $\begin{array}{l}\text { Low } \\
\text { High }\end{array}$ & $\begin{array}{l}1.00 \\
0.47\end{array}$ & 0.16 & 1.35 & & & & & \\
\hline pKDR-Y1775 & & & & $0.017^{a}$ & & & & $0.01^{a}$ \\
\hline $\begin{array}{l}\text { Negative } \\
\text { Positive }\end{array}$ & $\begin{array}{l}1.00 \\
4.02\end{array}$ & 1.28 & 12.63 & & $\begin{array}{l}1.00 \\
5.35\end{array}$ & 1.49 & 19.13 & \\
\hline MVD & & & & 0.35 & & & & \\
\hline $\begin{array}{l}\text { Low } \\
\text { High }\end{array}$ & $\begin{array}{l}1.00 \\
0.59\end{array}$ & 0.19 & 1.80 & & & & & \\
\hline
\end{tabular}

Although anti-angiogenic therapy has resulted in a complete revolution in the treatment of metastatic RCC patients, the response varies widely from patient to patient in terms of PFS and OS, no apparent explanation is found in most cases (Motzer et al, 2007, 2009). Certainly, it is the differential grade in the outcome that justifies the need to identify biomarkers that can predict the clinical benefit of sunitinib.

In addition to clinical and laboratory-based factors used as prognostic criteria, being MSKCC the most known (Motzer et al, 1999), several molecules have been explored as potential biologic indicators in terms of response to SU11248. Some of these studies have showed association between levels of VEGF-A soluble isoforms and PFS (Paule et al, 2010; Porta et al, 2010). Other recent studies have found an association between several proteins involved in hypoxia and SU11248 efficacy as well as low VEGFR3 expression associated with worse outcome (Garcia-Donas et al, 2013). Circulating endothelial cells as well as circulating bone marrow-derived progenitor cells have also been explored as valuable biomarkers (Gruenwald et al, 2010; Farace et al, 2011). Even at genetic level, novel studies have revealed a differential outcome based on the presence of polymorphisms in VEGF and VEGFR genes (Scartozzi et al, 2013) or based on miRNA expression profiles (Gamez-Pozo et al, 2012). Terakawa et al (2013) suggested that it would be useful to consider the expression levels of KDR to identify the metastatic RCC patients likely to be benefited from treatment with sunitinib; although several biomarkers were studied, only VEGFR2 expression appeared to be independently related to PFS as well as OS on multivariate analysis. In the analysis carried out in our panel of patients, we described for the first time the correlation of pKDR-Y1175 expression with PFS and OS in patients with metastatic RCC in terms of clinical benefit of sunitinib-based therapy.

Presently, little is known about the predictive role of pKDRY1175 in response to treatment. The phosphorylation profile and the intracellular location of KDR were investigated in both normal and neoplasic kidneys (Fox et al, 2004). Although the phosphorylated epitopes were different from our marker (Y1059 and Y1214), this study showed that $\mathrm{pKDR}$ is present in a wide variety of renal tumours, suggesting that anti-VEGFR therapy might have direct effects on tumour cells. Furthermore, pKDR-Y1775 has been associated with poor prognosis in endometrial carcinomas (Giatromanolaki et al, 2006).

Angiogenesis and its signalling proteins have been largely studied in several tumour types and their importance in tumour progression is widely accepted. However, their role in the modulation of response to anti-angiogenic therapies in cancer is still under debate. Some evidences recently showed correlations between angiogenesis and response to tyrosine kinase inhibitors that target receptors of angiogenesis (Rosa et al, 2013), including sunitinib. Supporting this research, our analysis provides novel 


\begin{tabular}{|c|c|c|c|c|c|c|c|c|}
\hline & \multicolumn{4}{|c|}{ Univariate OS analysis } & \multicolumn{4}{|c|}{ Multivariate OS analysis } \\
\hline & \multirow[b]{2}{*}{ HR } & \multicolumn{2}{|c|}{$95 \% \mathrm{Cl}$} & \multirow[b]{2}{*}{$P$} & \multirow[b]{2}{*}{ HR } & \multicolumn{2}{|c|}{$95 \% \mathrm{Cl}$} & \multirow[b]{2}{*}{$P$} \\
\hline & & Lower & Upper & & & Lower & Upper & \\
\hline Age & 1.00 & 0.95 & 1.04 & 0.98 & & & & \\
\hline Gender & & & & 0.08 & & & & 0.15 \\
\hline $\begin{array}{l}\text { Male } \\
\text { Female }\end{array}$ & $\begin{array}{l}1.00 \\
2.87\end{array}$ & 0.87 & 9.44 & & $\begin{array}{l}1.00 \\
2.6\end{array}$ & 0.7 & 9.64 & \\
\hline ECOG & & & & 0.15 & & & & \\
\hline $\begin{array}{l}0 \\
1-2\end{array}$ & $\begin{array}{l}1.00 \\
4.5\end{array}$ & 0.57 & 35.01 & & & & & \\
\hline No. of disease sites & & & & 0.2 & & & & \\
\hline $\begin{array}{l}1 \\
\geqslant 2\end{array}$ & $\begin{array}{l}1.00 \\
2.17\end{array}$ & 0.65 & 7.23 & & & & & \\
\hline MSKCC risk factors & & & & 0.06 & & & & 0.19 \\
\hline $\begin{array}{l}\text { Favourable } \\
\text { Intermediate }\end{array}$ & $\begin{array}{l}1.00 \\
2.93\end{array}$ & 0.96 & 8.95 & & $\begin{array}{l}1.00 \\
2.24\end{array}$ & 0.65 & 7.73 & \\
\hline VEGF & & & & 0.22 & & & & \\
\hline $\begin{array}{l}\text { Low } \\
\text { High }\end{array}$ & $\begin{array}{l}1.00 \\
2.59\end{array}$ & 0.56 & 11.95 & & & & & \\
\hline KDR & & & & 0.21 & & & & \\
\hline $\begin{array}{l}\text { Low } \\
\text { High }\end{array}$ & $\begin{array}{l}1.00 \\
0.48\end{array}$ & 0.15 & 1.51 & & & & & \\
\hline pKDR-Y1775 & & & & $0.015^{a}$ & & & & $0.02^{\mathrm{a}}$ \\
\hline $\begin{array}{l}\text { Negative } \\
\text { Positive }\end{array}$ & $\begin{array}{l}1.00 \\
5.34\end{array}$ & 1.39 & 20.5 & & $\begin{array}{l}1.00 \\
5.13\end{array}$ & 1.25 & 21.05 & \\
\hline MVD & & & & 0.22 & & & & \\
\hline $\begin{array}{l}\text { Low } \\
\text { High }\end{array}$ & $\begin{array}{l}1.00 \\
0.44\end{array}$ & 0.12 & 1.64 & & & & & \\
\hline
\end{tabular}

data of the role of active angiogenesis in RCC patients to predict the benefit of sunitinib. These findings require further validation in additional clinical series to confirm the potential impact in terms of outcome prediction.

\section{ACKNOWLEDGEMENTS}

This study was supported by the Biobank of Fundación Jiménez Díaz Hospital, CONSOLIDER-Consortium (CSD2009-00080) and by grants RD12/0036/0051, RD09/0076/0101, PI12/01552, PI10/02518 from ISCIII and S2010/BMD2344.

\section{CONFLICT OF INTEREST}

The authors declare no conflict of interest.

\section{REFERENCES}

Castellano D, Ravaud A, Schmidinger M, De Velasco G, Vazquez F (2013) Therapy management with sunitinib in patients with metastatic renal cell carcinoma: key concepts and the impact of clinical biomarkers. Cancer Treat Rev 39: 230-240.
Connolly DT (1991) Vascular permeability factor: a unique regulator of blood vessel function. J Cell Biochem 47: 219-223.

Chaudhary R, Bromley M, Clarke NW, Betts CD, Barnard RJ, Ryder WD, Kumar S (1999) Prognostic relevance of micro-vessel density in cancer of the urinary bladder. Anticancer Res 19: 3479-3484.

Farace F, Gross-Goupil M, Tournay E, Taylor M, Vimond N, Jacques N, Billiot F, Mauguen A, Hill C, Escudier B (2011) Levels of circulating CD45(dim)CD34(+)VEGFR2 $(+)$ progenitor cells correlate with outcome in metastatic renal cell carcinoma patients treated with tyrosine kinase inhibitors. Br J Cancer 104: 1144-1150.

Ferlay J, Parkin DM, Steliarova-Foucher E (2010) Estimates of cancer incidence and mortality in Europe in 2008. Eur J Cancer 46: 765-781.

Fox SB, Turley H, Cheale M, Blazquez C, Roberts H, James N, Cook N, Harris A, Gatter K (2004) Phosphorylated KDR is expressed in the neoplastic and stromal elements of human renal tumours and shuttles from cell membrane to nucleus. J Pathol 202: 313-320.

Gamez-Pozo A, Anton-Aparicio LM, Bayona C, Borrega P, Gallegos Sancho MI, Garcia-Dominguez R, de Portugal T, Ramos-Vazquez M, Perez-Carrion R, Bolos MV, Madero R, Sanchez-Navarro I, Fresno Vara JA, Espinosa Arranz E (2012) MicroRNA expression profiling of peripheral blood samples predicts resistance to first-line sunitinib in advanced renal cell carcinoma patients. Neoplasia 14: 1144-1152.

Garcia-Donas J, Leandro-Garcia LJ, Gonzalez Del Alba A, Morente M, Alemany I, Esteban E, Arranz JA, Climent MA, Gallardo E, Castellano DE, Bellmunt J, Mellado B, Puente J, Moreno F, Font A, Hernando S, Robledo M, Rodriguez-Antona C (2013) Prospective study assessing hypoxia-related proteins as markers for the outcome of treatment with 
sunitinib in advanced clear-cell renal cell carcinoma. Ann Oncol 24: 2409-2414.

Giatromanolaki A, Koukourakis MI, Turley H, Sivridis E, Harris AL, Gatter KC (2006) Phosphorylated KDR expression in endometrial cancer cells relates to HIF1alpha/VEGF pathway and unfavourable prognosis. Mod Pathol 19: 701-707.

Gruenwald V, Beutel G, Schuch-Jantsch S, Reuter C, Ivanyi P, Ganser A, Haubitz M (2010) Circulating endothelial cells are an early predictor in renal cell carcinoma for tumor response to sunitinib. BMC Cancer 10: 695 .

Kamba T, McDonald DM (2007) Mechanisms of adverse effects of anti-VEGF therapy for cancer. Br J Cancer 96: 1788-1795.

Kashyap MK, Kumar A, Emelianenko N, Kashyap A, Kaushik R, Huang R, Khullar M, Sharma SK, Singh SK, Bhargave AK, Upadhyaya SK (2005) Biochemical and molecular markers in renal cell carcinoma: an update and future prospects. Biomarkers 10: 258-294.

Krause DS, Van Etten RA (2005) Tyrosine kinases as targets for cancer therapy. $N$ Engl J Med 353: 172-187.

McMahon G (2000) VEGF receptor signaling in tumor angiogenesis. Oncologist 5(Suppl 1): 3-10.

Mendel DB, Laird AD, Xin X, Louie SG, Christensen JG, Li G, Schreck RE, Abrams TJ, Ngai TJ, Lee LB, Murray LJ, Carver J, Chan E, Moss KG, Haznedar JO, Sukbuntherng J, Blake RA, Sun L, Tang C, Miller T, Shirazian S, McMahon G, Cherrington JM (2003) In vivo antitumor activity of SU11248, a novel tyrosine kinase inhibitor targeting vascular endothelial growth factor and platelet-derived growth factor receptors: determination of a pharmacokinetic/pharmacodynamic relationship. Clin Cancer Res 9: 327-337.

Motzer RJ, Bacik J, Murphy BA, Russo P, Mazumdar M (2002) Interferon-alfa as a comparative treatment for clinical trials of new therapies against advanced renal cell carcinoma. J Clin Oncol 20: 289-296.

Motzer RJ, Hutson TE, Tomczak P, Michaelson MD, Bukowski RM, Oudard S, Negrier S, Szczylik C, Pili R, Bjarnason GA, Garcia-del-Muro X, Sosman JA, Solska E, Wilding G, Thompson JA, Kim ST, Chen I, Huang X, Figlin RA (2009) Overall survival and updated results for sunitinib compared with interferon alfa in patients with metastatic renal cell carcinoma. J Clin Oncol 27: 3584-3590.

Motzer RJ, Hutson TE, Tomczak P, Michaelson MD, Bukowski RM, Rixe O, Oudard S, Negrier S, Szczylik C, Kim ST, Chen I, Bycott PW, Baum CM, Figlin RA (2007) Sunitinib versus interferon alfa in metastatic renal-cell carcinoma. N Engl J Med 356: 115-124.

Motzer RJ, Mazumdar M, Bacik J, Berg W, Amsterdam A, Ferrara J (1999) Survival and prognostic stratification of 670 patients with advanced renal cell carcinoma. J Clin Oncol 17: 2530-2540.

Motzer RJ, Michaelson MD, Redman BG, Hudes GR, Wilding G, Figlin RA, Ginsberg MS, Kim ST, Baum CM, DePrimo SE, Li JZ, Bello CL, Theuer CP, George DJ, Rini BI (2006a) Activity of SU11248, a multitargeted inhibitor of vascular endothelial growth factor receptor and platelet-derived growth factor receptor, in patients with metastatic renal cell carcinoma. J Clin Oncol 24: 16-24.

Motzer RJ, Rini BI, Bukowski RM, Curti BD, George DJ, Hudes GR, Redman BG, Margolin KA, Merchan JR, Wilding G, Ginsberg MS, Bacik J, Kim ST, Baum CM, Michaelson MD (2006b) Sunitinib in patients with metastatic renal cell carcinoma. JAMA 295: 2516-2524.

Nakagawa M, Emoto A, Hanada T, Nasu N, Nomura Y (1997) Tubulogenesis by microvascular endothelial cells is mediated by vascular endothelial growth factor (VEGF) in renal cell carcinoma. Br J Urol 79: 681-687.

Pallares J, Rojo F, Iriarte J, Morote J, Armadans LI, de Torres I (2006) Study of microvessel density and the expression of the angiogenic factors VEGF, bFGF and the receptors Flt-1 and FLK-1 in benign, premalignant and malignant prostate tissues. Histol Histopathol 21: 857-865.
Paule B, Bastien L, Deslandes E, Cussenot O, Podgorniak MP, Allory Y, Naimi B, Porcher R, de La Taille A, Menashi S, Calvo F, Mourah S (2010) Soluble isoforms of vascular endothelial growth factor are predictors of response to sunitinib in metastatic renal cell carcinomas. PLoS One 5: e10715.

Porta C, Paglino C, De Amici M, Quaglini S, Sacchi L, Imarisio I, Canipari C (2010) Predictive value of baseline serum vascular endothelial growth factor and neutrophil gelatinase-associated lipocalin in advanced kidney cancer patients receiving sunitinib. Kidney Int 77: 809-815.

Rini BI (2009) Vascular endothelial growth factor-targeted therapy in metastatic renal cell carcinoma. Cancer 115: 2306-2312.

Rosa R, Damiano V, Nappi L, Formisano L, Massari F, Scarpa A, Martignoni G, Bianco R, Tortora G (2013) Angiogenic and signalling proteins correlate with sensitivity to sequential treatment in renal cell cancer. $\mathrm{Br} J$ Cancer 109: 686-693.

Scartozzi M, Bianconi M, Faloppi L, Loretelli C, Bittoni A, Del Prete M, Giampieri R, Maccaroni E, Nicoletti S, Burattini L, Minardi D, Muzzonigro G, Montironi R, Cascinu S (2013) VEGF and VEGFR polymorphisms affect clinical outcome in advanced renal cell carcinoma patients receiving first-line sunitinib. Br J Cancer 108: 1126-1132.

Schueneman AJ, Himmelfarb E, Geng L, Tan J, Donnelly E, Mendel D, McMahon G, Hallahan DE (2003) SU11248 maintenance therapy prevents tumor regrowth after fractionated irradiation of murine tumor models. Cancer Res 63: 4009-4016.

Senger DR, Brown LF, Claffey KP, Dvorak HF (1994) Vascular permeability factor, tumor angiogenesis and stroma generation. Invasion Metastasis 14: 385-394.

Takahashi A, Sasaki H, Kim SJ, Tobisu K, Kakizoe T, Tsukamoto T, Kumamoto Y, Sugimura T, Terada M (1994) Markedly increased amounts of messenger RNAs for vascular endothelial growth factor and placenta growth factor in renal cell carcinoma associated with angiogenesis. Cancer Res 54: 4233-4237.

Takahashi T, Yamaguchi S, Chida K, Shibuya M (2001) A single autophosphorylation site on KDR/Flk-1 is essential for VEGFA-dependent activation of PLC-gamma and DNA synthesis in vascular endothelial cells. EMBO J 20: 2768-2778.

Tannir NM, Plimack E, Ng C, Tamboli P, Bekele NB, Xiao L, Smith L, Lim Z, Pagliaro L, Araujo J, Aparicio A, Matin S, Wood CG, Jonasch E (2012) A phase 2 trial of sunitinib in patients with advanced non-clear cell renal cell carcinoma. Eur Urol 62: 1013-1019.

Terakawa T, Miyake H, Kusuda Y, Fujisawa M (2013) Expression level of vascular endothelial growth factor receptor-2 in radical nephrectomy specimens as a prognostic predictor in patients with metastatic renal cell carcinoma treated with sunitinib. Urol Oncol 31: 493-498.

Tomisawa M, Tokunaga T, Oshika Y, Tsuchida T, Fukushima Y, Sato H, Kijima H, Yamazaki H, Ueyama Y, Tamaoki N, Nakamura M (1999) Expression pattern of vascular endothelial growth factor isoform is closely correlated with tumour stage and vascularisation in renal cell carcinoma. Eur J Cancer 35: 133-137.

Zama IN, Hutson TE, Elson P, Cleary JM, Choueiri TK, Heng DY, Ramaiya N, Michaelson MD, Garcia JA, Knox JJ, Escudier B, Rini BI (2010) Sunitinib rechallenge in metastatic renal cell carcinoma patients. Cancer 116: 5400-5406.

This work is published under the standard license to publish agreement. After 12 months the work will become freely available and the license terms will switch to a Creative Commons AttributionNonCommercial-Share Alike 3.0 Unported License. 